\title{
PENILAIAN AUTENTIK DALAM PEMBELAJARAN BAHASA ARAB
}

\author{
Salamah$^{1}$, Rifqi Aulia Rahman², M. Elfan Kaukab ${ }^{3}$
}

\begin{abstract}
ABSTRAK
Tujuan penelitian ini adalah mengetahui faktor pendukung dan faktor penghambat guru dalam menerapkan penilaian autentik, serta mengetahui hasil penilaian autentik dalam pembelajaran bahasa arab. Aktivitas dalam analisis data yaitu data reduction, data display, dan conclusion drawing/verification. Penilaian autentik dalam pembelajaran bahasa arab kelas IV MI Ma'arif Kalibeber Wonosobo sudah cukup efektif. Pelaksanaan penilaian autentik dalam pembelajaran bahasa arab kelas IV di MI Ma'arif Kalibeber Wonosobo memiliki beberapa faktor yang mendukung diantaranya kegiatan belajar siswa yang menyenangkan, alat peraga yang terpenuhi, kesiapan siswa dan guru serta waktu yang pas. Sedangkan faktor yang menghambat pelaksanaan penilaian autentik diantaranya peserta didik yang kurang disiplin dalam mengikuti pelajaran, peserta didik yang kurang kemampuannya dalam hal pemahaman, belum bisa membaca bahasa arab dan memahami arti.
\end{abstract}

Kata kunci: Penilaian Autentik, Metode Pembelajaran, Pembelajaran Bahasa

\section{ABSTRACT}

The purpose of this study was to determine the supporting factors and inhibiting factors of teachers in implementing authentic assessment and to find out the results of authentic assessments in learning Arabic. Activities in data analysis are data reduction, data display, and conclusion drawing/verification. Authentic assessment in learning Arabic class IV at MI Ma'arif Kalibeber Wonosobo is quite effective. The implementation of authentic assessments in learning Arabic class IV at MI Ma'arif Kalibeber Wonosobo has several supporting factors including fun student learning activities, fulfilled teaching aids, student and teacher readiness, and the right time. While the factors that hinder the implementation of authentic assessment include students who are less disciplined in following lessons, students who lack ability in terms of understanding, cannot read Arabic, and understand the meaning.

Keywords: Authentic Assessment, Learning Methods, Language Learning

\footnotetext{
$\overline{1,2}$ Fakultas Ilmu Tarbiyah dan Keguruan, Universitas Sains Al-Qur'an Wonosobo

${ }^{3}$ Fakultas Ekonomi dan Bisnis, Universitas Sains Al-Qur'an Wonosobo
} 
PENDAHULUAN

Menurut Undang-Undang Nomor 20 Tahun 2003 tentang Sistem Pendidikan Nasional dikatakan bahwa kurikulum adalah seperangkat rencana dan pengaturan mengenai isi dan bahan pelajaran serta cara yang digunakan sebagai pedoman penyelenggaraan kegiatan belajar mengajar (Sanjaya, 2011). Kurikulum mempunyai kedudukan sentral dan strategis dalam seluruh proses pendidikan (Sukmadinata, 2002). Kurikulum mengarahkan segala bentuk aktivitas pendidikan untuk tercapainya tujuan pendidikan. Dengan kata lain bahwa kurikulum sebagai instrumental input untuk mencapai tujuan pendidikan yaitu pengembangan manusia yang sesuai dengan falsafah hidup bangsa. Kurikulum sebagai alat untuk mencapai tujuan pendidikan nasional harus mampu mengantarkan peserta didik menjadi manusia yang beriman dan bertakwa kepada Tuhan Yang Maha Esa, berakhlak mulia, sehat, berilmu, cakap, kreatif, mandiri dan menjadi warga negara yang demokratis serta bertanggung jawab, tidak hanya sebagai mata pelajaran, yang harus dibelajarkan kepada peserta didik, melainkan sebagai aktivitas pendidikan yang direncanakan untuk dialami dan diwujudkan dalam perilaku peserta didik.

Penilaian adalah proses yang sistematis dan berkesinambungan untuk mengumpulkan informasi tentang keberhasilan belajar peserta didik dan bermanfaat untuk meningkatkan efektivitas pembelajaran. Ketika memberi penilaian seorang pengajar hendaknya memberi penilaian bukan semata-mata berdasarkan ukuran angka untuk kegiatan belajar tertentu, tetapi harus meelakukan usaha perbaikan kualitas atau prestasi pelajar ditingkat pelajaran berikutnya dan memberi pembinaan motivasi belajar yang kuat (Izzan, 2011).

Diberlakukannya kurikulum 2013 yang menekankan pada pembelajaran berbasis aktivitas, maka penilaiannya lebih menekankan pada penilaian proses baik pada aspek sikap, pengetahuan, dan keterampilan. Penilaian autentik merupakan ciri khas Kurikulum 2013. Penilaian autentik ini merupakan penilaian yang dilakukan secara komprehensif untuk menilai dari masukan (input), proses, dan keluaran (output) pembelajaran (Kunandar, 2014). Penilaian autentik harus mencerminkan masalah dunia nyata, bukan dunia sekolah. Menggunakan berbagai cara dan kriteria yang holistik (kompetensi utuh merefleksikan pengetahuan, keterampilan, dan sikap).

Penilaian proses pembelajaran menggunakan pendekatan penilaian autentik (Authentic Asessment) yang menilai kesiapan siswa, proses dan hasil belajar secara utuh. Keterpaduan 
penilaian ketiga komponen tersebut akan menggambarkan kapasitas, gaya, dan proses belajar siswa atau bahkan mampu menghasilkan dampak instruksional (instructional effect) dari pembelajaran. Hasil penilaian autentik dapat digunakan oleh guru untuk merencanakan program perbaikan (remidial) pengayaan (enrichment) atau pelayanan konseling. Selain itu hasil penelitian autentik dapat digunakan sebagai bahan untuk memperbaiki proses pembelajaran sesuai standar penilaian pendidikan. Oleh karena itu penilaian autentik dilakukan bukan hanya terhadap hasil belajar, tetapi juga terhadap proses pembelajaran (Majid, 2013).

Belajar bahasa arab berbeda dengan belajar bahasa ibu, oleh karena itu prinsip dasar pengajarannya harus berbeda, baik menyangkut metode (model pengajaran), materi maupun proses pelaksanaan pengajarannya. Dalam proses pembelajaran bahasa arab, ada tiga aspek penting yang saling terkait satu sama lain, yaitu materi yang diajarkan, proses mengajarkan materi dan hasil dari proses pembelajaran. Proses pembelajaran akan terlaksana dengan baik bila guru dapat merencanakan dan mengelola kelas dengan baik. Dengan kata lain guru tidak hanya bertanggung jawab menyampaikan materi pelajaran didalam kelas, tapi seorang guru juga bertanggung jawab membina siswa dan memecahkan permasalahan belajar yang dihadapi oleh siswa sehingga mereka betul-betul mampu untuk mandiri menggunakan fakta, konsep, prinsip, dan teori-teori yang telah didapat dalam kelas dan mereka juga dapat menentukan permasalahan yang diberikan oleh guru (Roida \& Nidia, 2017).

Penilaian autentik sangat baik dilakukan untuk seluruh tingkat satuan pendidikan. Tetapi permasalahannya, beberapa guru di satuan pendidikan masih merasa kesulitan dalam penerapan teknik penilaian autentik ini. Berdasarkan hasil wawancara dengan Amminatun, S.Ag. selaku guru Bahasa Arab di MI Ma'arif Kalibeber Wonosobo, penilaian autentik sangat sulit dijalankan ketika murid terlalu banyak sedangkan waktu pembelajaran sangat singkat dan kurangnya sarana dari pihak madrasah seperti internet, surat kabar dan lainnya dalam menyelesaikan proyek. Beliau juga mengatakan bahwa penilaian autentik di dalam KTSP lebih ringkas dan tidak terlalu sulit dalam pengimplementasiannya sedangkan di dalam kurikulum 2013 penilaian autentik terlalu banyak komponen penilaiannya sehingga membuat guru lebih kesulitan dalam mengimplementasikannya. Terlebih penilaian autentik ini menyajikan rubik yang tergolong jelas, dan menyajikan nilai 
secara deskriptif bukanlah persoalan yang mudah. Penilaian yang menuntut observasi sebelum-sesudah dilaksanakannya kegiatan pembelajaran. Dan tidak selamanya teori semudah menerapkannya di lapangan.

\section{KAJIAN TEORI}

\section{Teori Hakikat Penilaian}

Ada beberapa istilah yangsering dipergunakan dalam konteks penilaian yang tidak jarang dikacaukan penggunanya. Istilah-istilah itu adalah penilaian (evaluation), pengukuran (measurement), tes (test), dan asesmen (assessment). Gronlud dengan jelas membedakan antara tes, pengukuran, dan evaluasi. Tes merupakan sebuah instrumen atau prosedur yang sistematis untuk mengukur suatu sampel tingkah laku. Pengukuran merupakan proses untuk memperoleh deskripsi angka (skor) yang menunjukkan tingkat capaian seseorang dalam suatu bidang tertentu. Penilaian merupakan proses sistematis dalam pengumpulan, analisis, dan penafsiran informasi untuk menentukan seberapa jauh seorang peserta didik dapat mencapai tujuan pendidikan. Pengertian asesmen sebenarnya sama dengan pengertian penilaian (Nurgiyantoro, 2018). Sesuai dengan informasi yang diberikan dalam salinan Permendikbud no 81.a tentang Implementasi Kurikulum 2013 memiliki beberapa karakteristik penilaian yang perlu dipahami guru yaitu belajar tuntas, autentik, berkesinambungan, berdasarkan acuan kriteria, menggunakan teknik penilaian bervariasi (Nyoman \& Ni, 2018).

\section{Penilaian Autentik}

Abdul Majid mengemukakan pengertian penilaian autentik yaitu: "Proses pengumpulan informasi oleh guru tentang perkembangan dan pencapaian pembelajaran yang dilakukan anak didik melalui berbagai teknik yang mampu mengungkapkan, membuktikan atau menunjukkan secara tepat bahwa tujuan pembelajaran dan kemampuan (kompetensi) telah benar-benar dikuasai dan dicapai” (Majid, 2013). Penilaian autentik juga diartikan sebagai "kegiatan menilai peserta didik yang menekankan pada apa yang seharusnya dinilai, baik proses maupun hasil dengan berbagai instrumen penilaian yang disesuaikan dengan tuntutan kompetensi yang ada di Standar Kompetensi (SK) atau Kompetensi Inti (KI) dan Kompetensi Dasar (KD)" (Kunandar, 2014).

Istilah penilaian autentik sering disejajarkan pengertiannya dengan performance asessment, alternative asessment, direct asessment, dan realistic asessment (Majid, 2013). Berdasarkan devinisi diatas, maka peneliti menyimpulkan bahwa penilaian autentik 
adalah kegiatan untuk mengetahui hasil belajar siswa dengan menggunakan proses pengumpulan, pelaporan, tentang hasil belajar siswa dengan menerapkan prinsipprinsip penilaian, pelaksanaan berkelanjutan, menggunakan bukti-bukti yang dapat dipercaya, asli, tulen atau sah.

\section{Pembelajaran Bahasa Arab}

Pembelajaran bahasa Arab adalah kegiatan mengajar yang dilakukan secara maksimal oleh guru agar anak didik yang ia ajari bahasa Arab tertentu melakukan kegiatan belajar dengan baik, sehingga kondusif untuk mencapai tujuan belajar bahasa Arab. Tujuan pembelajaran bahasa adalah untuk menguasai ilmu bahasa dan kemahiran bahasa arab, seperti muthala'ah, muhadatsah, insya', nahwu, dan sharaf, sehingga memperoleh kemahiran berbahasa yang meliputi empat aspek kemahiran, yaitu kemahiran mnyimak, kemahiran membaca, kemahiran menulis dan kemahiran berbicara (Khalilullah, 2012).

\section{Penilaian Autentik dalam Pembelajaran}

\section{Bahasa Arab}

1. Perencanaan Penilaian Autentik dalam Pembelajaran Bahasa Arab

Pertama melakukan penentuan standar. Standar dimaksudkan sebagai sebuah pernyataan tentang apa yang harus diketahui atau dapat dilakukan pembelajar.
Disamping standar ada goal (tujuan umum) dan objektif(tujuan khusus), dan standar berada berada diantara keduanya. Standar dapat diobservasi (observable) dan diukur (measurable) ketercapaiannya. Di kurikulum dikenal adanya istilah standar kompetensi lulusan dan kompetensi dasar. Kompetensi lulusan adalah kualifikasi kemampuan lulusan yang mencakup sikap, pengetahuan, dan keterampilan (PP No. 19 Tahun 2005: 2), sedangkan kompetensi dasar adalah kompetensi atau standar minimal yang harus tercapai atau dikuasai pembelajar (Abidin, 2016).

Langkah kedua penentuan tugas autentik. Tugas Autentik adalah tugastugas yang secara nyata dibebankan kepada pembelajar untuk mengukur pencapaian kompetensi yang dibelajarkan, baik ketika kegiatan pembelajaran masih berlangsung atau ketika sudah berakhir. Pengukuran hasil pencapaian kompetensi pemelajar yang secara realistik dilakukan dikelas dapat bersifat model tradisional atau autentik sekaligus tergantung kompetensi yang diukur.

Langkah ketiga pembuatan kriteria. Kriteria merupakan pernyataan yang menggambarkan tingkat capaian dan buktibukti nyata capaian belajar subjek belajar dengan kualitas tertentu yang diinginkan. Kriteria lazimnya juga telah dirumuskan sebelum pelaksanaan pembelajaran. Dalam kurikulum berbasis kompetensi kriteria 
lebih dikenal dengan sebutan indikator. Pembuatan kriteria harus mengacu pada ketentuan-ketentuan yang selama ini dinyatakan baik, baik dalam arti efektif untuk keperluan penilaian hasil belajar. Ketentuan-ketentuan itu diantaranya harus diumuskan secara jelas, singkat padat, dapat diukur, dan karenanya haruslah dipergunakan kata-kata kerja operasional, menunjukkan pada tingkah laku hasil belajar, apa yang mesti dilakukan dan bagaimana kualitas yang dituntut, dan sebaiknya ditulis dalam bahasa yang dipahami oleh subjek didik.

Terahir dengan pembuatan rubrik. Rubik dapat dipahami sebagai sebuah skala penskoran (scoring scale) yang dipergunakan untuk menilai kinerja subjek didik untuk tiap kriteria terhadap tugastugas tertentu (Abidin, 2016). Dalam sebuah rubrik terdapat dua hal pokok yang harus dibuat, yaitu kriteria dan tingkat capaian kinerja (level of performance) tiap kriteria. Kriteria berisi hal-hal esensial standar (kompetensi) yang ingin diukur tingkat capaian kinerjanya yang secara esensial dan konkret mewakili standar yang diukur capainnya. Dalam sebuah rubrik, kriteria mungkin saja atau boleh juga dilabeli dengan kata-kata tertentu yang lebih mencerminkan isi, misalnya dengan kata-kata : unsur yang dinilai.

2. Pelaksanaan Penilaian Autentik dalam Pembelajaran Bahasa Arab
Pelaksanaan atau implementasi penilaian autentik dalam konteks kurikulum 2013 telah secara tegas dinyatakan dalam Permendikbud Nomor 66 Tahun 2013 tentang Standar Penilaian Pendidikan dipandang sebagai kriteria mengenai mekanisme, prosedur, dan instrumen penilaian hasil belajar peserta didik. Penilaian pendidikan sebagai proses pengumpulan dan pengelolaan informasi untuk mengukur pencapaian hasil belajar peserta didik mencakup penilaian autentik, penilaian diri, penilaian berbasis portofolio, ulangan, ulangan harian, ulangan tengah semester, ulangan akhir semester, ujian tingkat kompetensi, ujian mutu tingkat kompetensi, ujian nasional, dan ujian sekolah/madrasah.

3. Pelaporan Hasil Penilaian Autentik dalam Pembelajaran Bahasa Arab

Unsur penting dalam manajemen berbasis sekolah adalah partisipasi masyarakat, transparansi, dan akuntabilitas publik. Atas dasar itu, laporan kemajuan hasil belajar peserta didik dibuat sebagai pertanggungjawaban lembaga sekolah kepada orang tua/wali peserta didik, komite sekolah, masyarakat, dan instansi terkait lainnya. Laporan kemajuan hasil belajar peserta didik merupakan sarana komunikasi dan sarana kerja sama antara sekolah, orang tua, dan massyarakat yang bermanfaat baik bagi kemajuan belajar 
peserta didik maupun pengembangan sekolah.

\section{METODE PENELITIAN}

Penelitian ini merupakan penelitian lapangan (Field Research). Penelitian lapangan dapat juga dianggap sebagai pendekatan luas dalam penelitian kualitatif. Ide pentingnya adalah bahwa peneliti berangkat ke lapangan untuk mengadakan pengamatan tentang sesuatu fenomena dalam suatu keadaan alamiah. Dalam hal demikian maka pendekatan ini terkait erat dengan pengamatan berperan serta (Moleong, 2011).

Metode dalam pendekatan ini, penelitian dilakukan dalam situasi alamiah akan tetapi didahului oleh semacam intervensi (campur tangan) dari pihak peneliti. Intervensi ini dimaksudkan agar fenomena yang dikehendaki oleh peneliti dapat segera tampak dan diamati. Dengan demikian terjadi semacam kendali atau kontrol persial terhadap situasi di lapangan (Anwar, 2014). Tempat Penelitian adalah tempat dimana penelitian itu dilakukan. Tempat penelitian yang dilakukan penulis adalah di MI Ma'arif Kalibeber Wonosobo.

Analisis data dalam penelitian kualitatif, dilakukan pada saat pengumpulan data berlangsung, dan setelah selesai pengumpulan data dalam periode tertentu. Pada saat wawancara, peneliti sudah melakukan analisis terhadap jawaban yang diwawancarai. Bila jawaban yang diwawancarai setelah dianalisis terasa belum memuaskan, maka peneliti akan melanjutkan pertanyaan lagi, sampai tahap tertentu, diperoleh data yang dianggap kredibel. Miles and Huberman mengemukakan bahwa aktivitas dalam analisis data kualitatif dilakukan secara interaktif dan berlangsung secara terusmenerus sampai tuntas, sehingga datanya sudah jenuh. Aktivitas dalam analisis data yaitu data reduction, data display, dan conclusion drawing/verification (Sugiyono, 2011).

\section{Data Reduction (Reduksi Data)}

Mereduksi data berarti merangkum, memilih hal-hal yang pokok, memfokuskan pada hal-hal yang penting, dicari tema dan polanya. Dengan demikian data yang telah direduksi akan memberikan gambaran yang lebih jelas, dan mempermudah peneliti untuk melakukan pengumpulan data selanjutnya, dan mencarinya bila diperlukan.

\section{Data Display (Penyajian Data)}

Setelah direduksi, maka langkah selanjutnya adalah mendisplay data. Dalam penelitian kualitatif, penyajian data bisa dilakukan dalam bentuk uraian singkat, bagan, hubungan antar kategori, flowchart dan sejenisnya. Dengan mendisplay data, maka akan memudahkan untuk memahami apa yang terjadi, merencanakan kerja 
selanjutnya berdasarkan apa yang telah dipahami tersebut.

3. Conclusing Drawing/Verification

Langkah ketiga dalam analisis data kualitatif menurut Miles and Huberman adalah penarikan kesimpulan dan verifikasi. Kesimpulan tersebut untuk menjawab rumusan masalah yang dirumuskan sejak awal, dalam penelitian ini diharapkan temuan baru yang sebelumnya belum pernah ada.

\section{HASIL DAN PEMBAHASAN}

\section{HASIL}

\section{Perencanaan Penilaian Autentik}

\section{Dalam Pembelajaran Bahasa Arab}

\section{Kelas IV MI Ma'arif Kalibeber}

Penilaian autentik sering digambarkan sebagai penilaian atas perkembangan peserta didik, karena berfokus pada kemampuan mereka berkembang untuk belajar bagaimana belajar tentang subjek. Penilaian autentik harus mampu menggambarkan sikap, keterampilan, dan pengetahuan apa yang sudah atau belum dimilki oleh peserta didik, bagaimana mereka menerapkan pengetahuannya dalam hal apa mereka sudah atau belum mampu menerapkan perolehan belajar (Majid, 2013). Pemaparan Amminatun S.Ag. selaku guru bahasa Arab terkait dengan perencanaan penilaian autentik dalam pembelajaran bahasa arab kelas IV
MI Ma'arif Kalibeber yaitu mendalami Silabus, RPP, Merencanakan waktu penilaian,dan pemilihan materi yang sesuai.

a. Silabus

Silabus merupakan seperangkat rencana dan pengaturan tentang kegiatan pembelajaran, pengelolaan kelas, dan penilaian hasil belajar. Pembuatan silabus ini disesuaikan dengan karakter materi yang sesuai dengan kurikulum dan dipertimbangkan berdasarkan ciri-ciri dan kebutuhan daerah setempat. Kemudian disesuaikan pula dengan karakteristik, potensi, dan kebutuhan peserta didik. Silabus dalam kurikulum 2013 telah disusun oleh MKKS (Musyawarah Kerja Kepala Sekolah) dan MGMP (Musyawarah Guru Mata Pelajaran), sehingga guru mata pelajaran tinggal mengukuti dan mendalami. Jika ada tambahan dan perubahan itu pun tidak banyak.

b. Menyusun RPP (Rencana Pelaksanaan Pembelajaran)

Sebelum mengadakan evaluasi atau penilaian tentunya didahului adanya rencana pelaksanaan pembelajaran (RPP). Menyusun rencana pelaksanaan pembelajaran (RPP) terlebih dahulu sebelum mengajar merupakan bagian penting dalam proses belajar mengajar. Dengan adanya RPP ini, seorang guru merasa lebih percaya diri berwibawa dalam berinteraksi dengan siswa di dalam 
kelas, karena mempunyai pedoman/panduan dalam mengajar. Penyusunan rencana pelaksanaan pembelajaran ini disesuaikan dengan karakter materi yang sesuai kurikulum dan dipertimbangkan berdasarkan ciri dan kebutuhan madrasah. Kemudian disesuaikan pula dengan karakteristik, potensi, dan kebutuhan peserta didik. Hal ini dilakukan sebelum pelaksanaan pengelolaan kelas demi memperoleh dan mencapai tujuan pembelajaran yang sebaik-baiknya. Tentunya jika pembelajaran berjalan dengan baik peserta didik akan mudah menerima materi yang disampaikan dan proses evaluasi akan diadakan sesuaikan dengan yang direncanakan untuk mengetahui sampai mana kemampuan peserta didik dalam menerima materi yang telah disampaikan oleh guru.

c. Waktu Penilaian

Waktu penilaian dilakukan pada saat kegiatan belajar sedang berlangsung. Hal ini dilakukan untuk memudahkan seorang guru dalam menilai peserta didiknya secara langsung apakah usaha yang dilakukan melalui pengajaran sudah mencapai tujuan atau belum.

\section{d. Materi yang sesuai}

Materi adalah bentuk bahan atau seperangkat substansi pembelajaran untuk membantu guru dalam kegiatan belajar mengajar yang disusun secara sistematis dalam rangka memenuhi standar kompetensi yang ditetapkan. Hal ini berarti bahwa materi pembelajaran yang dipilih untuk diajarkan oleh guru dan harus dipelajari siswa hendaknya berisikan materi yang benar-benar menunjang tercapainya standar kompetensi dasar. Adapun Kriteria dalam pemilihan materi yaitu 1) relevansi, bahwa materi yang disampaikan relevan dengan standar kompetensi dasar sebagai pelaksanaan kurikulum. 2) Konsisten/keajegan, materi pelajaran harus memiliki keajegan hal ini dikaitkan dengan prinsip bahwa materi yang diajarkan sesuai dengan keluasamn kompetensi dasarnya. Jika pada kompetensi dasar pada pelajaran bahasa arab kelas IV tercantum "mempraktikkan bunyi huruf, kata, frase, dan kalimat bahasa arab terkait topik perkenalan diri." Maka materi yang diajarkan harus meliputi pembahasan mengenai perkenalan diri. 3) Kecukupan, bahwa materi yang diajarkan tidak boleh terlalu dalam atau terlalu sedikit. Materi ajar yang disampaikan harus cukup memadai untuk membantu siswa mencapai kompetensi dasarnya.

\section{Aspek Pelaksanaan Penilaian Autentik Dalam Pembelajaran Bahasa Arab Kelas IV MI Ma'arif Kalibeber}

Menurut pemaparan ibu Amminatun, S.Ag. selaku guru bahasa arab kelas IV MI Ma'arif Kalibeber pelaksanaan penilaian 
autentik dalam pembelajaran bahasa arab kelas IV MI Ma'arif Kalibeber bahwa:

a. Pelaksanaan Penilaian Autentik

Direncanakan

Pelaksanaan merupakan suatu tindakan dari sebuah rencana yang sudah disusun secara matang dan terperinci, implementasi atau pelaksanaan biasanya dilakukan setelah perencanaan sudah dianggap siap. Seperti halnya dalam pelaksanaan penilaian autentik perlu adanya rencana agar pelaksanaan penilaian autentik berjalan dengan seperti yang diharapkan.

b. Pelaksanakan Pre Tes dan Post Tes

Pre Test yaitu suatu bentuk pertanyaan yang dilontarkan guru kepada muridnya sebelum memulai pelajaran tentang tema tertentu. Pertanyaan yang ditanya adalah materi yang akan diajar pada hari itu. Biasanya pertanyaan dilakukan guru di awal pembukaan pelajaran. Pre tes dilakukan dengan maksud untuk mengetahui mengenai materi yang akan diajarkan. Adapun manfaat dari diadakannya pretes adalah untuk mengetahui kemampuan awal peserta didik mengenai pelajaran yang disampaikan. Dengan mengetahui kemampuan awal peserta didik ini, guru akan dapat menentukan cara penyampaian yang akan ditempuh nanti.

Sedangkan post Tes itu sendiri merupakan bentuk pertanyaan yang diberikan setelah pelajaran/materi telah disampaikan. Yang mana seorang guru memberikan post tes dengan maksud apakah peserta didik sudah mengerti dan memahami mengenai materi dengan tema tertentu yang baru saja diberikan. Manfaat dari diadakannya post tes ini adalah untuk memperoleh gambaran tentang kemampuan yang dicapai setelah berakhirnya penyampaian pelajaran. Hasil post tes ini dibandingkan dengan hasil pre test yang telah dilakukan sehingga akan diketahui seberapa jauh efek atau pengaruh dari pengajaran yang telah dilakukan, disamping sekaligus dapat diketahui bagian-bagian mana dari bahan pengajaran yang masih belum dipahami oleh sebagian besar siswa.

c. Bentuk Kegiatan Evaluasi Yang Digunakan

Dalam kegiatan evaluasi kelas IV MI Ma'arif Kalibeber menerapkan dua bentuk kegiatan evaluasi yang digunakan yaitu tes formatif dan tes sumatif. Tes formatif adalah evaluasi yang dilakukan oleh guru selama dalam perkembangan atau dalam kurun waktu proses pelaksanaan suatu program pengajaran semester. Dengan maksud agar segera dapat mengetahui kemungkinan adanya penyimpanganpenyimpangan, ketidaksesuaian pelaksanaan dengan rencana yang telah disusun sebelumnya. Karena dilaksanakan setelah selesai mengajarkan satu unit 
pengajaran mungkin satu tema atau pokok bahasan maka ternyata apabila ada ketidaksesuaian dengan tujuan segera dapat dibetulkan. Sedangkan tes sumatif adalah evaluasi yang dilaksanakan oleh guru pada akhir semster. Jadi guru baru dapat melakukan evaluasi sumatif apabila guru yang bersangkutan selesai mengajarkan seluruh pokok bahasan yang merupakan porsi dari semester yang bersangkutan. Oleh karena itu evaluasi ini dimaksudkan untuk mengetahui tingkat keberhasilan yang dicapai peserta didik selama satu semester. Jadi fungsinya untuk mengetahui kemajuan peserta didik.

\section{d. Instrumen Test yang Digunakan}

Menurut pemaparan ibu Amminatun, S.Ag. selaku guru bahasa arab kelas IV MI Ma'arif Kalibeber dalam memilih instrumen penilaian memiliki beberapa standar yaitu melihat dari bagaimana karakteristik peserta didik, kemampuan peserta didik, materi dan juga ketersediaan sumber belajar. Program Tindak Lanjut Proses dan Hasil Belajar. Amminatun selaku guru bahasa arab MI Ma'arif Kalibeber mengatakan program tindak lanjut proses dan hasil belajar di kelas IV yaitu remidial atau pengayaan.

Kriteria Ketuntatasan Minimal (KKM) mata pelajaran bahasa arab kelas IV MI Ma'arif Kalibeber yaitu 6,7. Beliau membuat kriteria KKM tersebut melihat dari hasil tahun sebelumnya. Kemampuan setiap peserta didik itu berbeda-beda. Ada yang tuntas dan juga ada yang belum tuntas. Menindak lanjuti peserta didik yang mendapatkan nilai di bawah KKM yaitu dengan cara mengadakan remidial. Remidial diberikan kepada peserta didik untuk memperbaiki prestasi belajar sehingga mencapai kriteria ketuntasan yang ditetapkan. Pemberian program pembelajaran remidial didasarkan atas latar belakang bahwa guru perlu memperhatikan perbedaan individual peserta didik.

Sedangkan untuk program Pengayaan merupakan kegiatan yang diberikan kepada peserta didik yang melampaui persyaratan minimal dan tidak semua peseta didik dapat melakukannya.diadakannya program pengayaan yaitu belajar kelompok antar peserta didik hanya untuk kompotensi/materi yang belum diketahui peserta didik. Pembelajaran pengayaan dikaitkan dengan kegiatan penugasan terstruktur dan kegiatan mandiri tersetruktur. Penilaian hasil belajar kegiatan pengayaan, dihargai sebagai nilai tambah (lebih) dari peserta didik yang normal.

\section{Hasil Penilaian Autentik Dalam} Pembelajaran Bahasa Arab Kelas IV MI Ma'arif Kalibeber

Hasil penilaian autentik merupakan tahap akhir dalam proses penilaian. Hasil penilaian peserta dibuat laporan sebagai pertanggung jawaban lembaga sekolah 
kepada orang tua/wali peserta didik, komite sekolah, masyarakat dan instansi lainnya. Jenis pelaporan hasil penilaian autentik dalam pembelajaran bahasa arab kelas IV MI Ma'arif Kalibeber kepada orang tua/wali peserta didik berupa lapor yang secara administratif dilaporkan setiap satu semester.

4. Faktor Penghambat dan Pendukung Dalam Pelaksanaan Penilaian Autentik dalam Pembelajaran Bahasa Arab Kelas IV MI Ma'arif

\section{Kalibeber}

Faktor penghambat merupakan hal-hal yang mempengaruhi sedikit/bahkan menghentikan sesuatu menjadi lebih dari sebelumnya. Sedangkan faktor pendukung merupakan hal-hal yang mempengaruhi sesuatu menjadi berkembang, memajukan, menambah dan menjadi lebih dari sebelumnya. Diantara faktor penghambat dalam pelaksanaan penilaian autentik dalam pembelajaran bahasa arab kelas IV MI Ma'arif Kalibeber adalah peserta didik yang kurang disiplin, peserta didik yang kurang mampu dalam artian kemampuannya dalam menerima pelajaran bahasa arab itu kurang dalam hal pemahaman, belum bisa membaca bahasa arab, dan memahami arti. Adapun faktor pendukung dalam pelaksanaan penilaian autentik dalam pembelajaran bahasa arab kelas IV MI Ma'arif Kalibeber adalah kegiatan belajar siswa yang menyenangkan, alat peraga yang terpenuhi, kesiapan siswa dan guru serta waktu yang pas.

\section{PEMBAHASAN}

Ada beberapa hal yang penulis analisis terkait penilaian autentik dalam pembelajaran bahasa Arab kelas IV MI Ma'arif Kalibeber diantaranya yaitu :

a. Pelaksanaan Penilaian Autentik Direncanakan

Pelaksanaan penilaian autentik merupakan suatu tindakan dari sebuah rencana yang sudah disusun secara matang dan terperinci. Implementasi atau pelaksanaan biasanya dilakukan setelah perencanaan sudah dianggap siap. Seperti halnya dalam pelaksanaan penilaian autentik perlu adanya rencana agar pelaksanaan penilaian autentik berjalan dengan seperti yang diharapkan. Hal tersebut serupa sebagaimana yang dikemukakan oleh Tata S. bahwa evaluasi pendidikan secara garis besar melibatkan tiga unsur, yaitu input, proses, dan output. Apabila prosedur yang dilakukan tidak bercermin pada ketiga unsur tersebut, hasil evaluasi tidak mampu memberikan gambaran yang sesungguhnya terjadi dalam proses pembelajaran. Adapun dalam melaksanakan kegiatan evaluasi ada beberapa prosedur salah satunya perencanaan. Perencanaan yang dibuat menjawab pertanyaan-pertanyaan mengapa 
perlu adanya evaluasi, apa saja yang hendak dievaluasi, tujuan dari evaluasi, teknik apa yang hendak dipakai, siapa yang hendak dievaluasi, kapan, dimana, penyusun instrumen, indikator, data apa saja yang hendak digali dan sebagainya (Tatang, 2012).

\section{b. Pelaksanaan Pre Tes dan Post Tes}

Pelaksanaan pre tes dan post tes kelas IV dalam pembelajaran bahasa arab yang dilakukan oleh guru menurut penulis sudah memenuhi prosedur dalam pelaksanaan program pembelajaran melihat dari tujuan dari dilaksanakannya pre tes maupun post tes. Akan tetapi, menurut Ahmad Rohani supaya lebih efisien, mengadakan evaluasi baik pre tes maupun pre tes cukup dilaksanakan pada setiap akhir topik/pokok bahasan. Antara instrumen pre tes dan post tes hendaknya sama tetapi keduanya memiliki fungsi yang berbeda. Pre tes berfungsi menjajaki kemampuan yang akan diajarkan sedangkan post tes berfungsi mengukur/mengetahui taraf penguasaan materi yang telah dipelajari (Rohani, 2004).

c. Bentuk Kegiatan Evaluasi yang Digunakan

Bentuk kegiatan evaluasi yang digunakan dalam pembelajaran bahasa arab kelas IV yaitu tes formatif dan tes sumatif. Tes formatif itu sendiri adalah evaluasi yang dilakukan oleh guru selama dalam perkembangan atau dalam waktu proses pelaksanaaan suatu program pengajaran semester dengan tujuan untuk mengetahui kemungkinan adanya penyimpangan-penyimpangan,

ketidaksesuaian pelaksanaan dengan rencana yang telah disusun sebelumnya. Sedangkan tes sumatif dilaksanakan oleh guru pada akhir semester dengan tujuan untuk mengetahui tingkat keberhasilan yang dicapai peserta didik selama satu semester.

Menurut penulis hal di atas sesuai dengan teori dalam bukunya Ahmad Rohani bahwa penilaian formatif adalah jenis penilaian yang fungsinya untuk memperbaiki proses belajar mengajar dan waktu pelaksanaannya sesuai dengan fungsi dan tujuan penilaian yaitu dilakukan untuk hasil belajar jangka pendek dari suatu proses belajar mengajar/pada akhir unit pelajaran yang singkat seperti satu pelajaran. Penilaian sumatif adalah jenis penilaian yang fungsinya untuk menentukan angka kemajuan/hasil belajar peserta didik. Waktu pelaksanaanya sesuai dengan fungsi dan tujuan penilaian, maka penilaian sumatif ini dilakukan untuk menilai hasil belajar jangka panjang dari suatu proses belajar mengajar seperti pada akhir program pengajaran.

d. Instrumen Tes yang Digunakan Aspek Kognitif (Pengetahuan)

Instrumen tes yang digunakan pada aspek kognitif (pengetahuan) kelas IV MI 
Ma'arif Kalibeber adalah evaluasi harian dengan menggunakan tes isian singkat dan uraian, sedangkan untuk ulangan akhir semester ada pilihan ganda, isian singkat, dan uraian. Menurut penulis untuk evaluasi harian menggunakan tes isian singkat dan uraian sudah cukup untuk mengevaluasi sejauh mana pemahaman peserta didik tentang materi yang telah disampaikan. Karena dengan pemilihan instrumen tes dengan isian singkat dan uraian guru menjadi tahu seberapa kekuatan daya ingat peserta didik dalam memahami materi pelajaran yang ditanyakan dalam tes. Namun, pemilihan instrumen isian singkat dan uraian memiliki beberapa kelemahan seperti yang dikemukakan oleh Abdul Majid dalam bukunya Penilaian Autentik Proses dan Hasil Belajar bahwa tes isian singkat dan uraian memiliki beberapa kele,ahan diantaranya kadar validitas dan reabilitas rendah karena sukar diketahui segi-segi mana dari pengetahuan siswa yang betul-betul telah dikuasai, cara memeriksanya banyak dipengaruhi oleh unsur-unsur subjektif, seperti adanya hello effect, adanya efek bawaan, efek urutan pemeriksaan, pengaruh penggunaan bahasa, pengaruh tulisan tangan dan sebagainya. Pemeriksaannya lebih sulit sebab membutuhkan pertimbangan individual banyak dari penilai, dan waktu koreksinya lama dan tidak dapat diwakili kepada orang lain.

\section{Aspek Afektif (Sikap)}

Instrumen tes yang digunakan di kelas IV dalam pembelajaran bahasa arab aspek afektif tyaitu penilaian sejawat dan jurnal. Menurut penulis pemilihan instrumen tersebut sudah efektif untuk mengetahui aspek sikap siswa. Guru yang harus menilai masing-masing peserta didik akan sangat terbantu ketika penilaian teman sejawat dilakukan. Karena penilaian yang dilakukan oleh temannya sendiri biasanya lebih terbuka dari penilaian yang dilakukan oleh guru. Penilaian sejawat ini bagus, akan tahu pendapat teman lainnya, akan tahu kekurangannya, dan akan lebih memahami apa yang sebenarnya. Seperti yang dikemukakan oleh Chalijah Hasan bahwa afektif diartikan sebagai sikap, atau pernyataan pribadi terhadap sebuah objek. Afektif dibagi dalam beberapa bagian yakni, penerimaan, partisipasi, penilaian/penentuan sikap, organisasi, dan pembentukan pola hidup. Pengorganisasian pekerjaan afektif memang mempunyai ciri yang harus dibedakan dengan lapangan lainnya, dimana afektif lebih mengorientasikan pemasukan nilai-nilai norma-norma untuk diinternalisasikan dalam sistem kerja berikutnya (Hasan, 1994).

\section{Aspek Psikomotorik (Keterampilan)}

Instrumen tes yang digunakan pada aspek psikomotorik di kelas IV dalam pembelajaran bahasa arab yaitu dengan 
penilaian proyek dan praktik. Menurut penulis pemilihan instrumen tersebut sudah efektif untuk menilai keterampilan peserta didik. Tugas proyek dan praktik akan memberikan informasi tentang pemahaman dan pengetahuan peserta didik pada tema materi tertentu, kemampuan peserta didik dalam mengaplikasikan pengetahuan, kemampuan peserta didik mengomunikasikan informasi. Menurut Abdul Majid bahwa penilaian proyek sangat dianjurkan karena membantu mengembangkan keterampilan berpikir tinggi (berpikir kritis, pemecahan masalah, berpikir kreatif) peserta didik. Penilaian proyek dapat digunakan untuk mengetahui pemahaman, kemampuan mengaplikasikan, kemampuan penyelidikan dan kemampuan menginformasikan sesuatu secara jelas (Majid, 2013).

\section{Program Tindak Lanjut Proses dan Hasil}

\section{Belajar}

Program tindak lanjut proses dan hasil belajar kelas IV MI M'arif Kalibeber dalam pembelajaran bahasa arab adalah remidial atau pengayaan. Menurut penulis remidila atau pengayaan memang harus dilakukan disetiap jenjang pendidikan untuk menuju belajar tuntas. Belajar tuntas merupakan suatu pola pengajaran yang terstruktur yang bertujuan untuk mengadaptasikan pengajaran kepada kelompok peserta didik yang besar sedemikian rupa, sehingga diberikan perhatian secukupnya pada perbedaanperbedaan yang terdapat diantara siswa, khususnya yang menyangkut laju kemajuan atau kecepatan dalam belajar. Akan tetapi sebaiknya remidial diberikan dengan memperhatikan kesulitan belajar tiap peserta didik. Karena tingkat kesulitan yang dialami peserta didik berbedaa dan beragam, maka siswa yang mengikuti kegiatan remidial berdasarkan tingkat kesulitannya.

\section{PENUTUP}

Penilaian autentik dalam pembelajaran bahasa arab kelas IV MI Ma'arif Kalibeber sudah cukup efektif. Hal ini bisa dilihat dari mulai perencanaan penilaian autentik yang disusun secara matang oleh guru bahasa arab yaitu mendalami silabus, RPP, merencanakan waktu penilaian dan pemilihan materi yang sesuai. Aspek pelaksanaan penilaian autentik dalam pembelajaran bahasa arab kelas IV di MI Ma'arif Kalibeber meliputi aspek Kognitif (pengetahuan), aspek afektif (sikap), dan aspek psikomotorik (keterampilan). Penilaian pengetahuan meliputi tes isian singkat, uraian, dan pilihan ganda. Penilaian sikap meliputi penilaian sejawat dan jurnal. Penilaian terampilan meliputi penilaian proyek dan praktik.

Pelaksanaan penilaian autentik dalam pembelajaran bahasa arab kelas IV di MI 
Ma'arif Kalibeber memiliki beberapa faktor yang mendukung diantaranya kegiatan belajar siswa yang menyenangkan, alat peraga yang terpenuhi, kesiapan siswa dan guru serta waktu yang pas. Sedangkan faktor yang menghambat pelaksanaan penilaian autentik diantaranya peserta didik yang kurang disiplin dalam mengikuti pelajaran, peserta didik yang kurang kemampuannya dalam hal pemahaman, belum bisa membaca bahasa arab dan memahami arti.

Hasil penilaian autentik dalam pembelajaran bahasa arab kelas IV MI Ma'arif Kalibeber Tahun Ajaran 2018/2019 dari data hasil nilai yang penulis peroleh peserta didik banyak yang sudah mencapai KKM dan ada beberapa yang belum. Hasil penilaian autentik dalam pembelajaran bahasa arab dibuat laporan berupa rapor dilakukan setiap satu semester dilaporkan kepada orang tua/wali.

\section{DAFTAR PUSTAKA}

Abidin, Y. (2016). Desain Pembelajaran Dalam Konteks Kurikulum. PT Refika Aditama.

Anwar, S. (2014). Metode Penelitian. Pustaka Pelajar.

Hasan, C. (1994). Dimensi-Dimensi Psikologi Pendidikan. Al Ikhlas.

Izzan, H. A. (2011). Metodologi pembelajaran bahasa Arab. Humaniora Utama Press.

Khalilullah, M. (2012). Media Pembelajaran Bahasa Arab. Aswaja Presindo.

Kunandar. (2014). Penilaian Autentik (Penilaian Hasil Belajar Peserta Didik Berdasarkan Kurikulum 2013.
PT Raja Grafindo Persada.

Majid, A. (2013). Penilaian Autentik Proses dan Hasil Belajar. PT Remaja Rosdakarya.

Moleong, L. J. (2011). Metodologi Penelitian Kualitatif. PT Remaja Rosdakarya.

Nurgiyantoro, B. (2018). Penilaian Autentik dalam Pembelajaran Bahasa. Gadjah Mada University Press.

Nyoman, P., \& Ni. (2018). Literasi di Sekolah dari Teori dan Praktik. Ruzz Media.

Rohani, A. (2004). Pengelolaan Pengajaran. PT Rineka Cipta.

Roida, F., \& Nidia. (2017). Pembelajaran Bahasa Arab Di SMA Negeri 2 Kota Jambi dengan Metode dan Medianya. Fakultas Ilmu Budaya Universitas Jambi.

Sanjaya, W. (2011). Kurikulum dan Pembelajaran. Kencana.

Sugiyono, P. (2011). Metodologi penelitian kuantitatif kualitatif dan R\&D. Alpabeta, Bandung.

Sukmadinata, N. S. (2002). Pengembangan kurikulum teori dan praktek.

Tatang, S. (2012). Ilmu Pendidikan. CV Pustaka Setia. 